Reprod. Nutr. Dévelop., 1980, 20 (6), 1751-1765.

\title{
Influence of nutritional status on the daily patterns of nitrogen excretion in the carp (Cyprinus carpio L.) and the rainbow trout (Salmo gairdneri R.)
}

\author{
par S. J. KAUSHIK
}

with the technical assistance of Denise BLANC

Laboratoire de Nutrition des Poissons, I. N. R. A. Sf Pée sur Nivelle, 64310 Ascain, France.

Summary. Nitrogen (ammonia and/or urea) excretion in carp and rainbow trout kept under different feeding regimes was continuously monitored over $24-\mathrm{hr}$ cycles. The daily nitrogen excretion patterns resulting from these feeding regimes were studied over several days after a change from one mode to another.

Constant levels of endogenous nitrogen excretion were reached about one week after the start of a fasting period; almost one week was needed for the daily nitrogen excretion pattern to stabilize after the feeding rhyth $m$ was changed. Overall daily nitrogen excretion rates were directly related to nitrogen consumption in carp as well as in trout. The rate of ammonia excretion increased immediately after each meal ; the maximum rate occurred at different intervals, depending on the amount of nitrogen intake as well as on the time-lapse after a particular feeding regime was initiated. Contrary to data on sockeye salmon, post-digestive nitrogen excretion rate was distinctly different from the ENE rates observed during fasting in carp and rainbow trout.

\section{Introduction.}

Kinetic studies on post-prandial changes in blood free amino acid or sugar levels have been used to evaluate the absorption of these nutrients in homeotherms. These same blood levels have been periodically measured in fish (Nose, 1972 ; Zébian, 1977 ; Kaushik, 1977 ; Fauconneau and Luquet, 1979). Salmonid nitrogen excrefion rates were measured by Burrows (1964), Brett and Zala (1975) and Rychly and Marina (1977) who showed a post-prandial increase in ammonia excretion, the peak values being observed at different intervals ( $4 \mathrm{hrs}$ in the sockeye salmon, $6 \mathrm{hrs}$ in the trout and $11 \mathrm{hrs}$ in the coho) after feeding.

A new methodological approach has been used in this study to continuously measure the nitrogen excretion of fish kept in running water. Endogenous nitrogen excretion (ENE) was initially measured in fish fasted for a 4-week period. In order to see if the adaptive changes in fish refed after such fasting were different from those in fed fish undergoing a change in feeding rhythm, the feeding levels were modified and the daily patterns of nitrogen excretion rates were observed on different days following these changes. 


\section{Material and methods.}

The fish were maintained in a circular trough with a conical bottom. This type of trough, used currently in our laboratory for digestibility studies in fish (Kaushik and Luquet, 1976 ; Choubert ef al., 1979), has the advantage of evacuating any parliculate matter within seconds of its appearance in the water column. The water-holding capacity of the tank was fixed at $40 \mathrm{l}$, and the adjustable inlet flow was set at a constant rate of $2 \mathrm{l} / \mathrm{min}$. The water temperature was continuously recorded with a thermograph. The fish were adapted to the experimental condifions and to a dry pellet diet (see composition in table 1) for a one-month period before excreted ammonia or urea nitrogen analysis was started.

TABLE 1

Composition of the experimental diet $(\mathrm{g} / \mathrm{kg}$ dry diet)

\begin{tabular}{|c|c|c|}
\hline $\begin{array}{l}\text { Herring meal } \ldots \ldots \ldots \ldots \ldots \\
\text { Mineral mix (Luquet, 1971) } \ldots \ldots \ldots \ldots \ldots \\
\text { Vitamin mix (EIFAC, 1971) } \ldots \ldots \ldots \ldots\end{array}$ & $\begin{array}{r}960 \\
20 \\
20\end{array}$ & \\
\hline $\begin{array}{l}\text { Protein Content }(\mathrm{N} \text {-Kjeldahl } \succ, 6.25) \ldots \ldots \\
\text { Energy content } \ldots \ldots \ldots \ldots \ldots \ldots \ldots\end{array}$ & \multicolumn{2}{|c|}{$\begin{array}{l}71.2 \text { p. } 100 \text { dry mater } \\
5138 \mathrm{kcal} / \mathrm{kg} \mathrm{d} . \mathrm{m} .\end{array}$} \\
\hline $\begin{array}{l}\text { Digestibility coefffcients }(p .100) \quad \ldots \ldots \\
\text { Dry matter } \ldots \ldots \ldots \ldots \ldots \ldots \ldots \\
\text { Nitrogen } \ldots \ldots \ldots \ldots \ldots \ldots \ldots \ldots \ldots \ldots \\
\text { Energy } \ldots \ldots \ldots \ldots \ldots \ldots\end{array}$ & $\begin{array}{l}\text { mean } \\
77.6 \\
91.2 \\
91.5\end{array}$ & 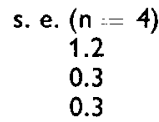 \\
\hline
\end{tabular}

a) Experimental procedure. - In the cycles mentioned in this study, the water flowing through the fish tank was continuously sampled and analyzed and data on ammonia and/or urea $\mathrm{N}$ concentrations were recorded over a 24-hr period. A cycle generally began at 8 a.m. on a given day and ended at 8 a.m. the next morning. The number following a day (e.g., day $n$ ) indicates that the $24 \mathrm{hr}$ cycle of analysis started at $8 \mathrm{a} . \mathrm{m}$. on the nth day after the start of the particular feeding regime.

b) Trials with carp. - Three carp (Cyprinus carpio L.) having a mean weight of $350 \mathrm{~g}$ were transferred to the experimental tank more than a month before the experiment started. Although very active and reluctant to eat any feed during their first week in the tank, they accepted the pelleted feed after a week. Following a preliminary adaptation period of one month (2 meals to satiation/day), the carp were subjected to a total fast and cycles of ammonia excretion analyses were conducted on days 4, 7 , 14 and 28. After this fast, the fish were fed one fixed meal of 1 p. 100 of body weight (BW)/day at a.m. Sampling was done on days 1, 4, 14 and 21 of this feeding procedure.

The fish were then adapled to a dietary regime of one meal fed to satiation every morning at 9 a.m. for a period of a month. Ammonia nitrogen was analysed in a series of three consecutive cycles after this adaptation period to verify if there were any significant day-to-day changes in the daily ammonia excretion pattern in the fish adapted to this feeding regime. The feeding procedure was then abruptly altered 
to 2 meals/day (given to satiation at 9 a.m. and 4 p.m.), and samples were taken on days $1,4,7,14,21$ and 28 . The water temperature was found to vary between 16 and $18^{\circ} \mathrm{C}$ during this experimental period.

c) Trials with rainbow trout. - Fifteen rainbow trout (Salmo gairdneri R.) with a mean BW of $130 \mathrm{~g}$ were adapted to the experimental conditions. After a month of adaptation, they were subjected to a complete fast and were sampled on days 4, 7, 14, 21 and 28 after the last meal. The fish were fed again with a single fixed meal of $20 \mathrm{~g}$ of the pelleted diet every day at 9 a.m. and the cycles were carried out on days 1, 4, 7 and 14 . After a short 24-hr fast, the feeding regime was again changed to 2 fixed meals of $10 \mathrm{~g}$ each at $9 \mathrm{a} . \mathrm{m}$. and $4 \mathrm{p} . \mathrm{m}$. The daily nitrogen excretion pattern was monitored on days 1, 4, 7 and 14 after this change. The trout were then fed a ration of 2 meals distributed to satiation every day at $9 \mathrm{a} . \mathrm{m}$. and 4 p.m. At the end of a month of adaptation to this feeding schedule, a single cycle of ammonia and urea-N analysis was run. The temperature of the water varied between 15 and $18^{\circ} \mathrm{C}$ during this trial period.

d) Analytical procedure. - The continuous analysis of ammonia or urea nitrogen in water was done by letting the sampler probe of an autoanalyzer (Technicon Autoanalyzer 1) in the fish tank and constantly recording the values on a recorder chart.

Ammonia- $N$ was determined by the colorimetric indophenol method using a slightly modified version of the manifold for automatic analysis given by Le Corre and Treguer (1976). The accuracy, reliability and reproducibility of this highly sensitive (0-4 $\mu$ atg $\mathrm{NH}_{4} \mathrm{~N} \mathrm{I}^{-1}$ ) method have been discussed by those authors. The sensitivity of the method was adjusted to cover the range of $0-200 \mu \mathrm{gH}_{4} \mathrm{~N} \mathrm{I}^{-1}$. When estimating $\mathrm{N}$ excretion of fasted fish, the upper limit was brought down to $50 \mu \mathrm{gH}_{4} \mathrm{NI}^{-1}$. Having tested other automated procedures for urea arialysis in water (De Manche ef al., 1973), we found that the sensitivity of these methods was not sufficient for measuring the microquantities of urea- $\mathrm{N}$ excreted by fish grown in running water. The manual method of Muravskaya (1973) was modified and adapted to automatic urea-N analysis in the range of $0-50 \mu \mathrm{g}$ urea- $\mathrm{N} \mathrm{I}^{-1}$. This method, using antipyrine $(0.8 \mathrm{p} .100$ in 60 p. $100 \mathrm{H}_{2} \mathrm{SO}_{4}$ ) and diacetyl monoxime (2.5 p. 100) (autoanalyzer pump rate $(\mathrm{ml} / \mathrm{min})$ : sample -2.5 ; air -0.32 ; antipyrine -0.8 ; diacetyl monoxime 0.16 ; heating bath $-95^{\circ} \mathrm{C} ; 50 \mathrm{~mm}$ flowcell and readings at $460 \mathrm{~nm}$ ), was highly sensitive and stable, as also shown by Siest (1966). All reagents in the analytical circuit were kept air-free (20 p. $\left.100 \mathrm{H}_{2} \mathrm{SO}_{4}\right)$.

Several preliminary runs of more than $24 \mathrm{hrs}$ were done to be sure that there was no base-line shift or possible alterations in reagent activities. Though the analytical system went unchanged for periods of up to and over $72 \mathrm{hrs}$, periodical controls were effected during every 24-hrs cycle to verify the efficiency of the whole system. Urea- $\mathrm{N}$ excretion was not determined for the carp.

The amount of $N$ excreted was calculated at any instant « $i$ » using the following formula :

$$
E_{t}=V_{0} \cdot \Delta C+C_{t} \cdot \Delta W
$$

where $\mathrm{V}_{0}=$ volume of water in the tank

$\Delta C=$ variation in $N\left(C_{i}-C_{i-t}\right)$ concentration

$C_{t}=$ mean of $N$ concentration between two consecutive intervals $\left(C_{i}+C_{i-t} / 2\right)$, 
$\Delta W=$ flow rate/unit of time « $t$ »

$t=$ unit of increment in time in which concentration variation is considered minimal and $E_{t}=N$ excreted by fish per unit of time retained. In the present work, « $t$ » was fixed at $30 \mathrm{~min}$. Statistical analysis was done according to the methods of Snedecor and Cochran (1969).

Kjeldahl nitrogen analyses were done on dry diet and freeze-dried samples of ground whole fish after wet digestion. The energy content of the diet was estimated by bomb calorimetry. Digestibility was measured using the automatic faeces collector described by Choubert et al. (1979).

\section{Results.}

a) Ammonia excrefion in carp.

Under fast. - The mean daily endogenous excretion rate for carp was $51.8 \mathrm{mg}$ $\mathrm{NH}_{4} . \mathrm{N} / \mathrm{kg} /$ day. Much fluctuation in the endogenous ammonia excretion rates occurred during the light hours of the cycles (figs. 1a, 2). Day-to-day fluctuation was also noted : the endogenous rates were $38.3,49.1,66.8,57.7$, and $47.2 \mathrm{mg} \mathrm{N} / \mathrm{kg} / \mathrm{day}$ for carp fasted for $4,7,14,21$ and 28 days, respectively.

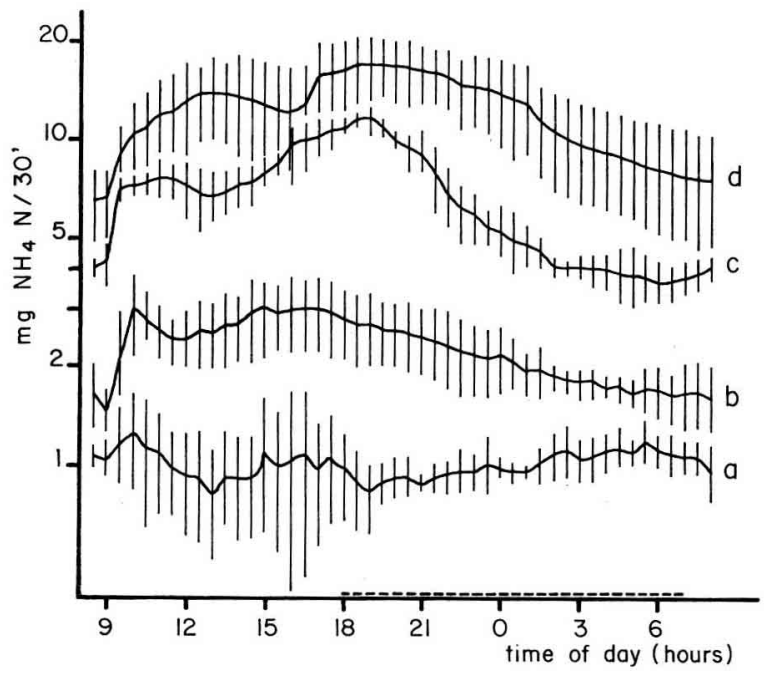

FIG. 1. - Daily patterns of ammonia excretion in carp : (a) fasted, (b) fed 1 fixed meal,

(c) fed 1 meal to satiation, (d) fed 2 meals to satiation (mean \pm s.e.).

Refed a fixed ration in a single meal per day (figs. $1 b, 3$ ). - The $\mathrm{N}$ consumption being fixed (576 $\mathrm{mg} \mathrm{N} / \mathrm{kg} \mathrm{BW} /$ day), the ration received was much below carp satiety levels, if we compare these fish with those fed to satiation (table 2). The daily ammonia excretion rates were $92,111,122,121$ and $105 \mathrm{mg} \mathrm{N} / \mathrm{kg}$, respectively, on days 1 , $4,7,14$ and 28 of this feeding regime. The proportion of $N$ excretion to intake was 19 p. 100. The rate of ammonia excretion increased on day 1 , immediately after carp 


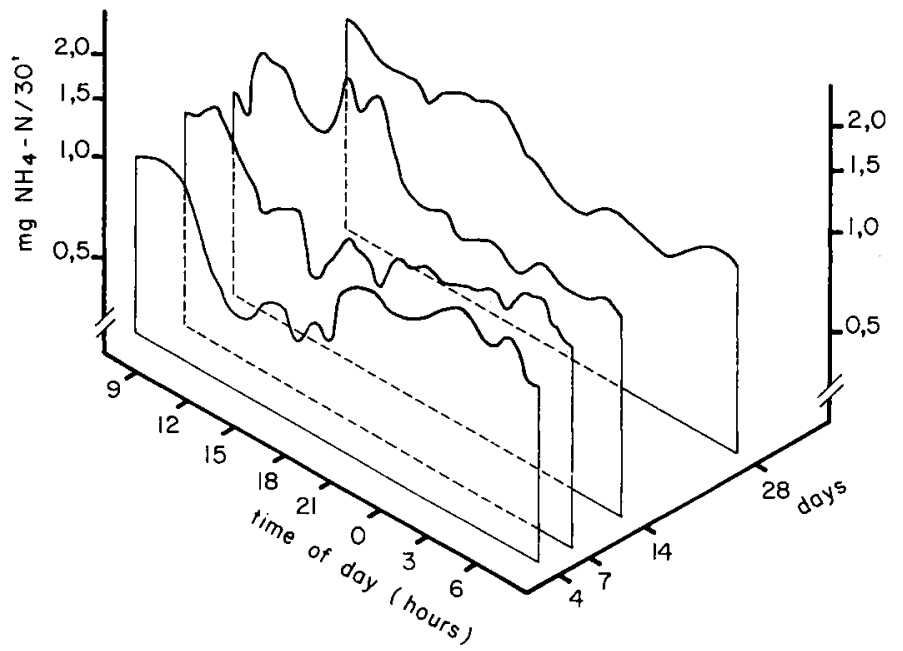

FIG. 2. - Development of ammonia excretion pattern in starved carp.

TABLE 2

Data on nitrogen intake and excretion in carp and rainbow trout depending on the levels of feeding All values as $\mathrm{mg} \mathrm{N} / \mathrm{kg} \mathrm{BW/day;} \mathrm{mean} \pm$ s.e. (n)

\begin{tabular}{|c|c|c|c|c|}
\hline \multirow[t]{3}{*}{ Cyprinus carpio } & \multirow[t]{3}{*}{ Fasted } & \multicolumn{3}{|c|}{ Fed } \\
\hline & & \multirow{2}{*}{$\begin{array}{l}\text { Fixed ration } \\
1 \text { meal/day }\end{array}$} & \multicolumn{2}{|c|}{ To satiation } \\
\hline & & & $1 \mathrm{meal} / \mathrm{day}$ & 2 meals $/$ day \\
\hline $\begin{array}{l}\text { Intake } \ldots \ldots \ldots \ldots \ldots \\
\text { Excretion ............. } \\
\text { p. } 100 \text { of intake lost as } \\
\text { ammonia- } N \ldots \ldots\end{array}$ & $\begin{array}{c}51.8 \pm \\
-\end{array}$ & $\begin{array}{l}576 \pm 20(5) \\
110 \pm 5.5(5) \\
19.1 \pm 1.2\end{array}$ & $\begin{array}{c}1075 \pm 80(3) \\
325 \pm 12(3) \\
30.2 \pm 2.3\end{array}$ & $\begin{array}{c}1673 \pm 80(7) \\
581 \pm 49(7) \\
34.7 \pm 3.0\end{array}$ \\
\hline \multirow[t]{3}{*}{ Salmo gairdneri } & Fasted & \multicolumn{3}{|c|}{ Fed } \\
\hline & & \multicolumn{2}{|c|}{ Fixed ration in } & To satiation \\
\hline & & $1 \mathrm{meal} / \mathrm{day}$ & $2 \mathrm{mea} / \mathrm{s} / \mathrm{day}$ & 2 meals/day \\
\hline 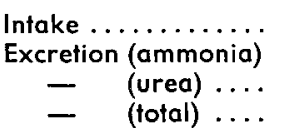 & $\begin{array}{l}0 \\
63.7 \pm 9.6(5) \\
20.1 \pm 2.6(3) \\
91.2 \pm 17.3(3)\end{array}$ & $\begin{array}{c}1143 \pm 19(4) \\
516.8 \pm 76(4) \\
83.1 \pm 4.1(4) \\
600 \pm 4(4)\end{array}$ & $\begin{array}{c}1062 \pm 16(4) \\
433.6 \pm 27(4) \\
474 \pm 3.5(5) \\
511.8 \pm 29(4)\end{array}$ & $\begin{array}{c}2213 \\
895.3 \\
72.7 \\
968\end{array}$ \\
\hline $\begin{array}{l}\text { p. } 100 \text { of intake lost as } \\
\text { ammonia }+ \text { urea.. }\end{array}$ & - & $52.5 \pm 2.7$ & $48.2 \pm 3.6$ & 43.7 \\
\hline
\end{tabular}

fasted for 28 days were fed, but it declined within $2 \mathrm{hrs}$ to below the basal level (fig. 3 ). By day 4 , the fish appeared to be adapted to the new feeding level, as far as daily excretion rate was concerned. The pattern of ammonia excretion however was subject to much change. The immediate post-prandial increase lost its importance by day 7. 


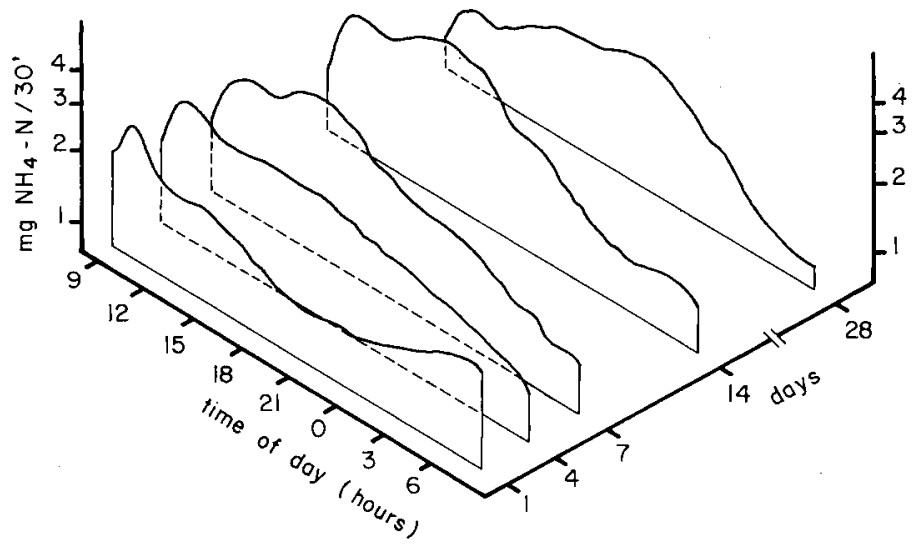

FIG. 3. - Development of ammonia excretion pattern in carp fed a single fixed ration per day.

Fed 1 meal to satiation per day. - After the fish had been adapted to this feeding regime for one month, total nitrogen excretion amounted to a mean of $325 \mathrm{mg} \mathrm{NH}$. $\mathrm{N} / \mathrm{kg} \mathrm{BW} /$ day (table 2). As shown in (fig. 1c), ammonia excretion increased twofold after feeding from a prefeeding level of $4 \mathrm{mg} \mathrm{N}$ to $8 \mathrm{mg} \mathrm{N}$. The peak value of the cycle however occurred about 8 to $10 \mathrm{hrs}$ after the morning meal, then rapidly declined to below prefeeding levels by midnight, with a slight increase during the early hours of the morning. About 30 p. 100 of the nitrogen consumed was lost through ammonia as metabolic wastes; this was a relatively higher loss than in carp fed a fixed ration.

Fed 2 meals to satiation per day (figs. 1d, 4). - The changes in the daily ammonia excretion patterns observed on different days after an abrupt change in feeding rhythm is presented in figure 4. Mean daily nitrogen intake as well as ammonia excretion

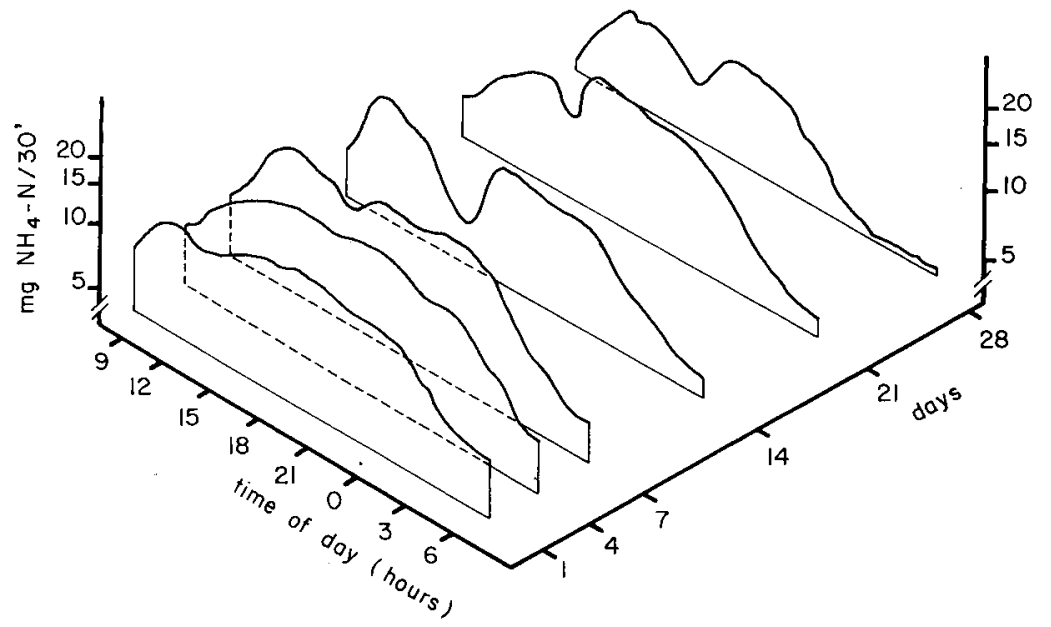

FIG. 4. - Development of ammonia excretion patterns in carp fed 2 meals to satiotion per day. 
increased (1673 and $581 \mathrm{mg} \mathrm{N} / \mathrm{kg} \mathrm{BW} /$ day, respectively) resulting in a $35 \mathrm{p.} 100$ loss of consumed nitrogen. The pre-feeding level was almost twofold higher (about $8 \mathrm{mg}$ of $N$ ) than in carp fed only once a day to satiation ; this high basal level was maintained until day 14 under this feeding regime. The excretion rate increased immediately after each meal ; its amplitude was very much accentuated on day 14 . During this cycle (d14), the first post-prandial increase declined to reach the pre-feeding rate before the fish received a second meal. In most of the cycles under this rhythm, two peaks in the ammonia excretion rates were observed : the first between noon and 2 p.m. and the second between 7 p.m. and 9 p.m. By day 21, the pre-feeding basal level of $\mathrm{NH}_{4} . \mathrm{N}$ excretion declined to that noted in carp fed a single meal ; this level was also reached much earlier during the cycle (about 3 a.m.) after day 14 . The total amount of nitrogen excreted as ammonia reached a high on day 7 , but stabilized subsequently: $576,757,771,529,453$ and $408 \mathrm{mg} \mathrm{N} / \mathrm{kg}$ /day on days $1,4,7,14,21$ and 28 , respectively.

\section{b) Nitrogen excretion in rainbow trout}

Fasted for 4 weeks. - The daily rates of endogenous ammonia excretion amounted to $99,47,68,56$, and $48 \mathrm{mg} \mathrm{N} / \mathrm{kg} /$ day, respectively, on days $4,7,14,21$ and 28 of fasting. The daily rate was apparently stabilized by one week, the mean endogenous rate being $64 \mathrm{mg} \mathrm{NH}{ }_{4} \mathrm{~N} / \mathrm{kg} /$ day. The day-to-day fluctuations were of greater amplitude during the light hours, as was noted with fasted carp (fig. 5). On day 4, these fluctuations were lower as compared to succeeding cycles. Endogenous urea- $\mathrm{N}$

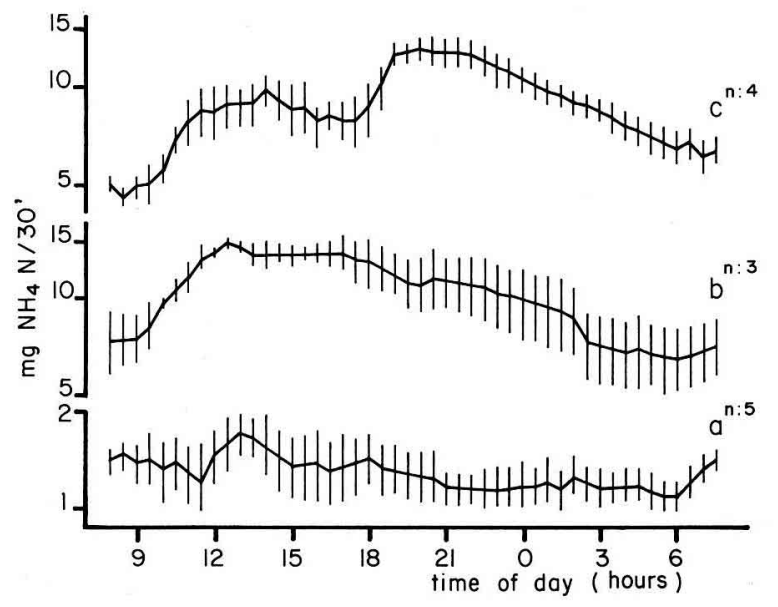

FIG. 5. - Ammonia excretion by trout : (a) fasted, (b) fed a fixed ration in 1 meal/day or (c) fed 2 meals/day (mean \pm s.e.).

excretion rate also varied during the rest of the 24-hr cycle (fig. 6). As urea-N excretion apparently decreased with days of fast (being 25,18 and $15 \mathrm{mg} u \mathrm{rea}-\mathrm{N} / \mathrm{kg} / \mathrm{day}$ on days 4,7 and 14, respectively), data could not be obtained on urea excretion in trout fasted for more than 14 days. The mean endogenous nitrogen excretion (ammonia + urea) was $91.2 \mathrm{mg} \mathrm{N} / \mathrm{kg} \mathrm{BW} /$ day. 


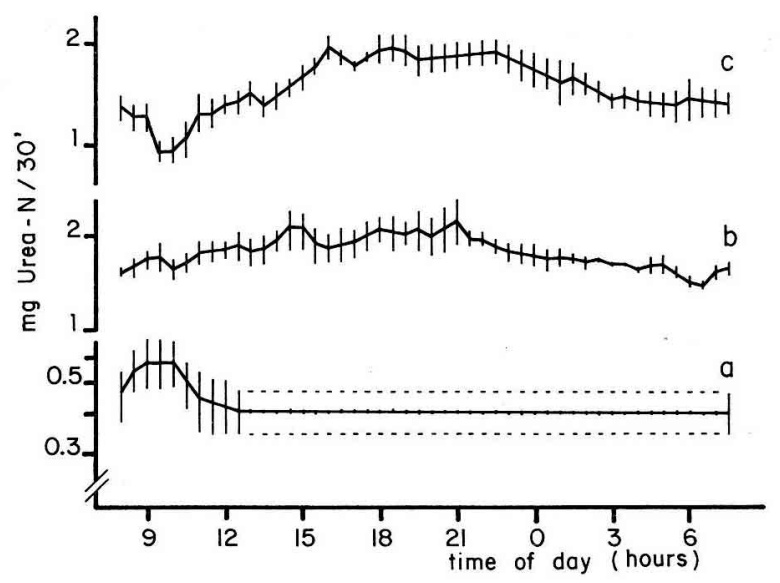

FIG. 6. - Urea excretion of trout : (a) fasted, (b) fed a fixed ration in 1 meal a day, (c) fed 2 meats a day (mean \pm s.e.).

Fed a fixed ration in a single meal (figs. $5 b, 66,7,9$ ). - Upon refeeding, the nitrogen excretion rates increased throughout the first day in an almost linear fashion ; the daily excretion rate was 189 and $46 \mathrm{mg} \mathrm{N} / \mathrm{kg} /$ day for ammonia and urea, respectively, at the end of that day. The maximal rates occurred 4,6 and more than 6 hrs after the morning meal on days, 4,7 and 14 respectively (fig. 7 ). The excretion rates were $593 \mathrm{mg} \mathrm{NH}{ }_{4} . \mathrm{N}$ and $79 \mathrm{mg}$ urea- $\mathrm{N} / \mathrm{kg} /$ day on day 4 ; on day 14 these rates were 593 and $87 \mathrm{mg} \mathrm{N} / \mathrm{kg} /$ day. $52 \mathrm{p} .100$ of consumed $\mathrm{N}$ was thus lost through ammonia and urea excretion by trout fed a fixed meal every morning.

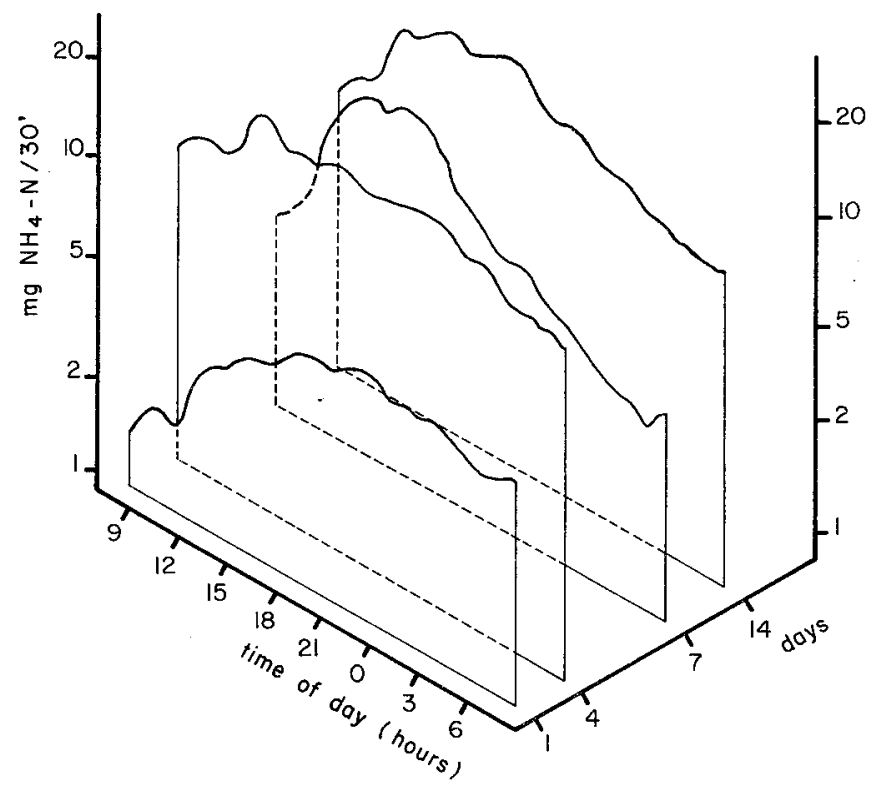

FIG. 7. - Development of ammonia excretion pattern in trout fed a fixed ration in 1 meal per day. 


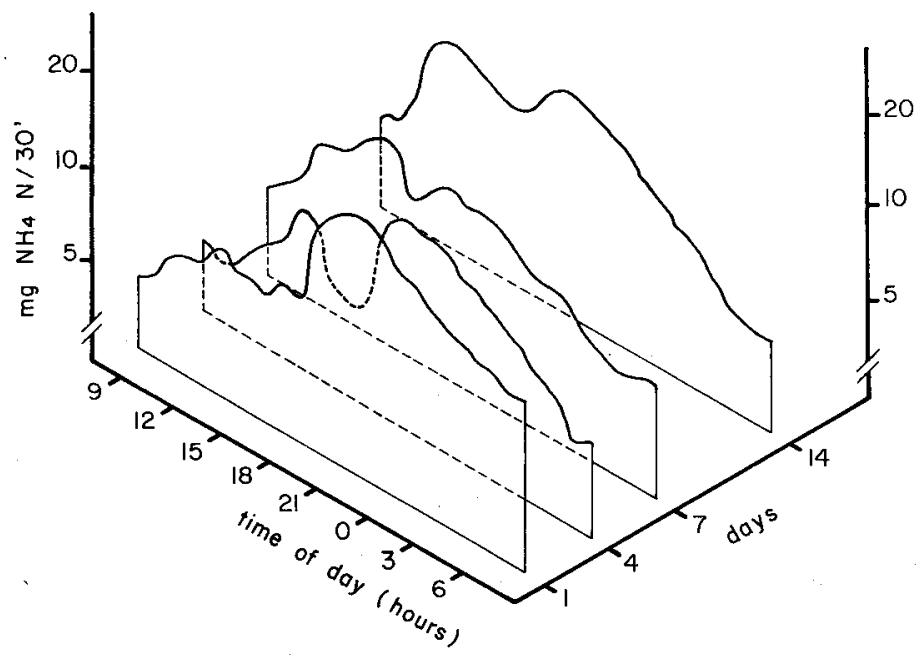

FIG. 8. - Development of ammonia excretion pattern in trout fed a fixed ration in 2 meals a day.

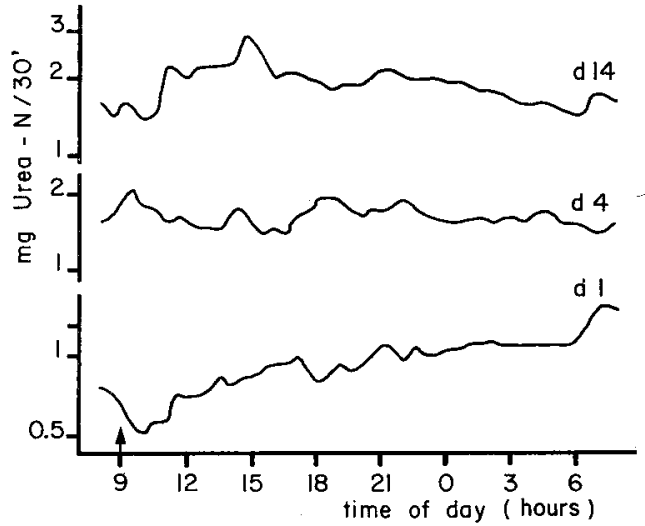

FIG. 9. - Development of urea excretion pattern in trout fed a fixed ration in 1 meal per day.

Fed the same amount in 2 meals per day (fig. $5 c, 6 c, 8,10$ ). - Trout generally excreted less nitrogen $(512 \mathrm{mg} \mathrm{N} / \mathrm{kg} / \mathrm{day}$ ) when fed the same amount of nitrogen in 2 meals instead of in one meal $(600 \mathrm{mg} \mathrm{N} / \mathrm{kg} /$ day). Although immediate post-prandial increases were observed after every meal until day 4 , under the changed rhythm, it appeared that the second meal of the day had a greater influence than the first on nitrogen excretion rates (figs. 8,10 ). While the pre-feeding basal levels of ammonia excretion rates remained the same on different days, the variation patterns were different. Although the peaks indicating the two rates were evident even on day 4, on day 7 two distinct excretion rate peaks, corresponding to the two meals, appeared. Urea- $\mathrm{N}$ excretion rates fluctuated, showing no pattern. The daily excretion rates for days 1, 4, 7 and 14 were 478, 376, 406 and $473 \mathrm{mg} \mathrm{NH}_{4} . \mathrm{N} / \mathrm{kg} /$ day and $70,72,72$ and $65 \mathrm{mg}$ urea- $\mathrm{N} / \mathrm{kg} /$ day, respectively. Nitrogen loss as ammonia + urea would account for 48 p. 100 of the nitrogen consumed under this feeding schedule. 


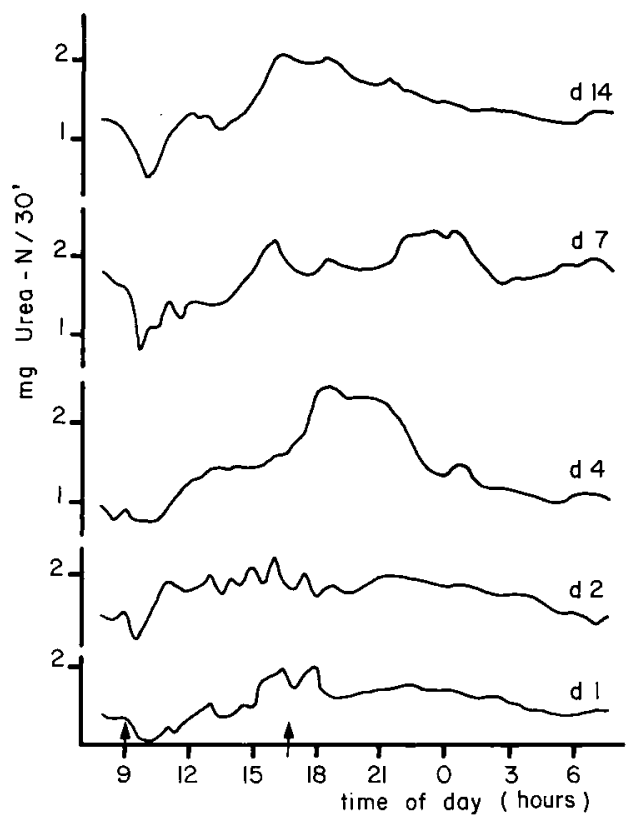

FIG. 10. - Development of urea excretion pattern in trout fed a fixed ration in 2 meals per day.

Fed 2 meals to satiation. - After a month of adaptation, the trout excreted $895 \mathrm{mg}$ $\mathrm{NH}_{4} \mathrm{~N} . / \mathrm{kg} \mathrm{BW} /$ day and $73 \mathrm{mg}$ of urea-N. The total $\mathrm{N}$ lost as ammonia and urea represented about 44 p. 100 of the consumed N. Nitrogen excretion reached a peak between 6 and 7 hrs after the second meal.

\section{Discussion.}

Salmonids require high-quality running water and ambient ammonia affects the nitrogen excretion rates. Hence, we preferred to estimate $\mathrm{N}$ excretion in a continuous manner in fish grown in normoxic, running water rather than to keep the fish in static water or in semi-closed circuits and measure $N$ excretion at fixed intervals.

Carp as well as trout accepted the high-protein diet very well. The apparent digestibility values obtained for rainbow trout are high (table 1 ), but no corresponding estimate was made for carp. While apparent digestibility increased with the use of such protein-rich diets, nitrogen excretion also increased due to the utilization of amino acids for energetic purposes. This led to an overall poor efficiency of the diet. But since we intended to observe separately the effect of $N$ consumption on the daily $N$ excretion patterns, this high-protein diet was used so as to minimize any interaction of the other ingredients in a compounded diet.

Endogenous nitrogen excretion (ENE)

Body composition analyses showed that trout under our fasting conditions lost about $4.52 \mathrm{~g} / \mathrm{kg} \mathrm{BW} / \mathrm{day}$, or an equivalent of $108 \mathrm{mg} \mathrm{N} / \mathrm{kg} / \mathrm{day}$, which is an unusually 
low value as compared to those obtained earlier (Nose, 1961 ; Kaushik, 1977) in trout of lower body weight. Considering that ammonia and urea represent 85 p. 100 of the total nitrogen excreted through the kidney and gills, the mean ENE rate for the same period ( $91 \mathrm{mg} \mathrm{N} / \mathrm{kg} /$ day) was not very different from the above or from the rate found by Fromm (1963) for trout of similar body weight.

Even if we consider that $\mathrm{NH}_{4} . \mathrm{N}$ represents but 60 to 70 p. 100 of the total- $\mathrm{N}$ excreted by carp (Delaunay, 1929 ; Smith, 1929), the basal ammonia excretion (52 mg $\mathrm{NH}_{4} . \mathrm{N} / \mathrm{kg} /$ day) was low in these fish as compared to values for total- $\mathrm{N}$ found earlier by Vellas (1973) in the same fish after an 8-day fast under otherwise similar conditions (autumn, fish weight : $350 \mathrm{~g}$ ), but this value is comparable to those of Ogino ef al. (1973). Vellas did not state the temperature used in her static water experiments. Contrary to sockeye salmon (Brett and Zala, 1975), the ENE rates of rainbow trout and carp increased with the onset of the natural light period (about 6 a.m.).

The mean ENE rates were calculated including data on different fasting cycles but it is important to note that the rates decrease with the days of fasting, and that there is an increase on day 14 for both trout and carp, contrary to what has been determined for most fish, i.e. the stable basal level of ENE is reached 6 to 8 days after the start of an experimental fast (Fromm, 1963 ; Savitz, 1971a ; Smith and Thorpe, 1976). Under starvation conditions, the cytoplasmic protein in the soft tissues is substantially reduced and the ENE of such fish may bear little resemblance to the ENE of well-fed fish. Nevertheless, the mean rates at any instant $(t=30 \mathrm{~min})$ during the different cycles were not statistically different after day 14.

Influence of feeding level and number of meals.

a) Daily nitrogen excretion patterns. - It would be expected that 4 weeks of starvation would affect the gastrointestinal tract and thereby adaptation to the first feeding regime, and that later adaptation to other feeding regimes would be less affected as the fish were already receiving food. But no evidence to this effect is apparent in this study. Upon refeeding after 4 weeks of fasting, the adaptive changes were delayed in carp, while the daily pattern in rainbow trout distinctly showed the impact of the meal by day 7.

Altering the feeding regime resulted in similar adaptive patterns. With a fixed ration such as one meal per day, the excretion rates reached maximal values within $6 \mathrm{hrs}$ after the meal in carp, while in trout those values appeared much earlier (around 3 to $4 \mathrm{hrs}$ after the meal) as in sockeye salmon. In carp fed to satiation once a day, the maximal rate occurred $10 \mathrm{hrs}$ after the morning meal, and the excretion rate was also higher than when they were fed a limited ration. During the 2 meals/day regime, the carp consumed almost equal quantities $(5.8 \pm 0.6 \mathrm{~g}$ of dry diet per meal) at every meal distributed to satiation, while the amount of feed distributed to trout remained constant. The two peaks of ammonia excretion rate, corresponding to the respective meals, were well established only 7 days after the number of meals increased. Under this regime, the maximal excretion rate in carp appeared almost at the same time as in carp fed a single meal, the second meal exerting only a slight influence, although $N$ intake was about the same at each meal. Similar observations were made in trout (figs. $5 b, c$ ). The volume of feed distributed or the amount of $\mathrm{N}$ consumed apparently 
had an influence on the interval needed for the rate of maximal post-prandial ammonia excretion to appear, whereas the number of meals did not affect such rates.

In sockeye salmon, Brett and Zala (1975) observed that the midnight plateau of $N$ excretion rate (post-digestive state) was not different from the stable ENE rate found after 22 days of starvation. Distinctly different results were obtained by us ; the pre-feeding level in carp, even when the fish were fully adapted to one meal per day, was much higher than the average ENE rate in the same fish. The differences in both ammonia and urea excretion are apparent in trout as well. Considering the mean transit rate of food passing through the digestive tract of rainbow trout (Possompes ef al., 1975), it is certain that a portion of the previous morning's meal was still being absorbed when the next meal was administered, leading to variations in pre-feeding rates of $\mathrm{N}$ excretion.

b) Daily rates of nitrogen excretion. - Savitz et al. (1977) showed in largemouth bass that it takes more than $24 \mathrm{hrs}$ for the $\mathrm{N}$ excretion to follow a change in the size of the meal. When carp, previously adapted to a single meal, are fed a larger number of meals, the total daily rates continue to increase during the first week and then stabilize. If the amount remains invariable, as in the case of rainbow trout, there is no great change in the daily rates. Rychly and Marina (1977) found a threefold increase in ammonia excretion in fed fish as compared to a starved group. Unfortunately, the nitrogen intake was not reported. Smith and Thorpe (1976) feeding rainbow trout (post-smolts, May-June) a known quantity of nitrogen, reported a mean loss of 39 p. 100 when the basal excretion rate was accounted for. Table 2 shows the proportionate loss of nitrogen to $\mathrm{N}$ intake in fish during the different trials. Trout fed twice a day lost almost the same proportion as ammonia and urea alone (39 p. 100 when corrected for ENE), while this loss was still higher (about 44 p. 100) in trout fed once a day. At low levels of nitrogen intake, the proportionate loss of nitrogen as ammonia is linear to $\mathrm{N}$ intake but at levels near satiation, the proportion does not seem to be affected.

TABLE 3

Equations describing the relationship between nitrogen intake (X) and nitrogen excretion (Y) by carp and rainbow trout ${ }^{(1)}$

\begin{tabular}{|c|c|c|c|}
\hline \multicolumn{4}{|l|}{ Rainbow Trout } \\
\hline$\overline{\mathrm{NH}_{4}-\mathrm{N}}$ & $\begin{aligned} Y & = \\
\log Y & =\end{aligned}$ & $\begin{aligned} & 62.254+0.375 \times \\
& 1.857+0.649 \times\left({ }^{2}\right)\end{aligned}$ & $\begin{array}{l}(r=0.969) \text { or } \\
(r=0.939)\end{array}$ \\
\hline Urea-N & $\begin{aligned} Y & = \\
\log Y & =\end{aligned}$ & $\begin{aligned} 29.411 & +0.033 \times \\
1.389 & +0.349 \times\left({ }^{2}\right)\end{aligned}$ & $(r=0.838)$ or \\
\hline Total (ammonia + urea) & $\begin{array}{r}Y= \\
\log Y= \\
\log Y=\end{array}$ & $\begin{array}{c}105.68+0.412 x \\
0.795+0.7914 \log x \\
2.046+0.557 \times(2)\end{array}$ & $\begin{array}{l}(r=0.971) \text { or } \\
(r=0.834) \text { or } \\
(r=0.923)\end{array}$ \\
\hline Carp & $\log Y=$ & $1.725+0.620 \times\left({ }^{2}\right)$ & $(r=0.968)$ \\
\hline
\end{tabular}

(1) $X$ and $Y$ expressed in terms of $\mathrm{mgN} / \mathrm{kg} B W /$ day.

(2) $X$ expressed in terms of grams instead of $\mathrm{mg}$. 
A complete nitrogen budget cannot be described, but it can 'be approximated as follows using the example of rainbow trout fed a fixed ration per day : digestible loss, 9 p. 100 ; branchial and urinary losses as ammonia and urea alone, 50 p. 100 ( 8 p. 100 of endogenous origin) ; utilization for growth, about 17 p. 100 during the trials (rather a low value probably due to the high proportion of fish meal in the dief).

Different mathematical functions have been used to explain the relationships between $N$ intake and $N$ excretion (Savitz, 1971b ; Savitz ef al., 1977). Table 3 gives the different equations which describe these relationships in our studies on trout and carp. The total daily $\mathrm{N}$ intake was treated as a whole, irrespective of the number of meals, as that number does not affect total $N$ excretion, provided that the total $N$ intakes do not differ.

c) Proportion of urea- $\mathrm{N}$ excreted. - The amount of urea excreted, as some proportion of the ammonia + urea excreted, varies in rainbow trout as in many other fish (Smith, 1929 ; Brett and Zala, 1975 ; Guerin-Ancey, 1976a, b). We find that, although urea- $\mathrm{N}$ excretion was linearly related to ammonia- $\mathrm{N}$ excretion in rainbow trout, this relation can be best described by the following equation :

$$
\mathrm{mg} \text { urea-N/kg BW/day }=25.4502 \log X-86.3454(\mathrm{r}=0.96)
$$

where $X=m g \mathrm{NH}_{4} . \mathrm{N} / \mathrm{kg} /$ day. This results in a decreasing proportion of urea with increasing rates of ammonia excretion. Burrow's (1964) observations of the shiftover of predominance of ammonia to that of urea excretion, due to variations in stocking density and/or temperature, are still to be demonstrated in other teleosts.

Differences in the daily patterns of nitrogen excretion rates are not only due to feeding levels but also to inherent adaptive mechanisms after a change in feeding rhythm, therefore great care must be taken in using intermittent measurement to evaluate the discharge of fish nitrogenous wastes.

Reçu en janvier 1980. Accepté en avril 1980.

Résumé. Une méthode nouvelle d'estimation en continu de l'excrétion azotée a été employée pour suivre l'évolution nychtémérale de la perte ammoniacale chez la carpe ef celle de l'ammoniaque et de l'urée chez la truie arc-en-ciel, élevées dans diverses conditions alimentaires (jeûne, 1 ou 2 repas/jour, repas restreint ou à volonté). L'adaptation de l'excrétion azotée à une modification de l'état nutritionnel a été étudiée en suivant leur évolution à différents intervalles après le changement.

L'excrétion azotée endogène (ENE) se stabilise au bout d'une semaine après le début d'un jeûne expérimental ; une semaine environ est également nécessaire pour la stabilisation de l'excrétion azotée après un changement dans le rythme alimentaire. La quantité tołale d'azote excrétée au cours d'un nychthémère est liée à la consommation azotée chez les deux espèces étudiées.

Une augmentation immédiate du taux d'excrétion ammoniacale est notée après chaque repas, quelque soit le mode de distribution. Les pics post-prandiaux de taux d'excrétion azotée sont notés à différentes périodes, en fonction et de la consommation azotée et de la durée d'adaptation des poissons au rythme alimentaire concerné.

\section{References}

BRETT J. R., ZALA C. A., 1975. Daily pattern of nitrogen excretion and oxygen consumption of sockeye salmon (Oncorhynchus nerka) under controlled conditions. J. Fish. Res. Board Can., 32, 2479-2486. 
BURROWS R. E., 1964. Effects of accumulated excretory products on hatchery-reared salmonids. Fish. Wildl. Serv., Bur. Sport Fish. Wildl. U. S. Res. Rep., 66, 1-12.

CHOUBERT G. Jr., DE LA NOUE J., LUQUET P., 1979. Continuous quantitative automatic collector for fish feces. Prog. Fish Cult., 41, 64-67.

De MANCHE J. M., CURL H. Jr., COUGHENOWER D. D., 1973. An automated analysis for urea in seawater. Limnol. Oceanogr., 19, 686-689.

DELAUNAY H., 1929. Sur l'excrétion azotée des poissons. C. R. Soc. Biol. Bordeaux, 101, 371-372.

EIFAC, 1971. Salmon and trout feeds and feeding. E. I. F. A. C. Tech. Pap., 12.

FAUCONNEAU B., LUQUET P., 1979. Influence d'une élévation de température sur l'évolution de l'aminoacidémie et de l'ammoniémie après le repas chez la truite arc-en-ciel (Salmo gairdneri R.). Ann. Biol. anim. Bioch. Biophys., 19, 1063-1079.

FROMM P., 1963. Studies on renal and extra-renal excretion in the freshwater teleost, Salmo gairdneri. Comp. Biochem. Physiol., 10, 121-128.

GUERIN-ANCEY O., 1976a. Etude expérimentale de l'excrétion azotée du bar (Dicentrarchus labrax) en cours de croissance. I. Effets de la température et du poids du corps sur l'excrétion d'ammoniac et d'urée. Aquaculture, 9, 71-80.

GUERIN-ANCEY O., 1976b. Etude expérimentale de l'excrétion azotée du bar (Dicentrarchus labrax) en cours de croissance. Il. Effets du jeûne sur l'excrétion d'ammoniac et d'urée. Aquaculture, 9, 187-194.

KAUSHIK S. J., 1977. Influence de la salinité sur le métabolisme azoté et le besoin en arginine chez la truite arc-en-ciel (Salmo gairdneri R.). Thèse d’Ełat, Univ. Bretagne Occidentale, Brest, France, 230 pp.

KAUSHIK S. J., LUQUET P., 1976. Ełude de la digestibilité des acides aminés de régimes à base de zéine chez la truite arc-en-ciel. Ann. Hydrobiol., 7, 11-19.

LE CORRE P., TREGUER P., 1976. Contribution à l'éfude de la matière organique dissoufe et des sels nutritifs dans l'eau de mer. Caractéristiques chimiques du Golfe de Gascogne ef des upwellings côtiers de l'Afrique du Nord-Ouest. Thèse d'Etat, Univ. Bretagne Occidentale, Brest, France, 490 pp.

LUQUET P., 1971. Efficacité des protéines en relation avec leur taux d'incorporation dans l'alimentation de la truite arc-en-ciel. Ann. Hydrobiol., 2, 175-186.

MURAVSKAYA Z. A., 1973. Determination of urea in seawater. Hydrobiol. J., 9, 81.

NOSE T., 1961. Determination of nutritive value of food protein in fish. I. On the determination of food protein utilization by carcass analysis. Bull. Freshwat. Fish. Res. Lab., Tokyo, 11, 29-42.

NOSE T., 1972. Changes in pattern of free plasma amino acids in rainbow trout after feeding. Bull. Freshwat. Fish. Res. Lab., Tokyo, 22, 137-144.

OGINO C., KAKINO J., CHEN M.-S., 1973. Protein nutrition in fish. II. Determination of metabolic fecal nitrogen and endogenous nitrogen excretions of carp. Bull. jap. Soc. scient. Fish., 39, 519-523.

POSSOMPES B. P., BERGOT P., LUQUET P., 1975. Mise au point d'une méthode d'étude du transit gastro-intestinal chez la truite arc-en-ciel Solmo gairdneri Richardson : Influence du nombre de repas, des quantités ingérées et de la température d'acclimatation. Ann. Hydrobiol., 6, 131-143.

RYCHLY J., MARINA B. A., 1977. The ammonia excretion of trout during a 24-hour period. Aquaculture, 11, 173-178.

SAVITZ J., 1971a. Effects of starvation on body protein utilization of bluegill sunfish (Lepomis macrochirus Rafinesque) with a calculation of caloric requirements. Trans. am. Fish. Soc., 100, 18-21.

SAVITZ J., 1971b. Nitrogen excretion and protein consumption of the bluegill sunfish (Lepomis macrochirus). J. Fish. Res. Board Can., 28, 449-451.

SAVITZ J., ALBANESE E., EVINGER M. J., KOLASINSKI P., 1977. Effect of ration level on nitrogen excretion, nitrogen retention and efficiency of nitrogen utilization for growth in largemouth bass (Micropterus solmoides). J. Fish. Biol., 11, 185-192.

SIEST G., 1966. Elude des réactions colorées de l'urée et des dérivés carbamides avec des alpha-dicétones : Applications biologiques. Thèse d'Ełat (Pharmacie), Univ. Nancy, France. 285 PP.

SMITH W. H., 1929. The excretion of ammonia and urea by the gills of fish. J. biol. Chem., 81, 727-743. 
SMITH M. A. K., THORPE A., 1976. Nitrogen metabolism and trophic input in relation to growth in freshwater and saltwater Salmo gairdneri. Biol. Bull., 150, 139-151.

SNEDECOR G. W., COCHRAN W. G., 1969. Statistical Methods. Iowa State Univ. Press, lowa, USA, 534 PP.

VELLAS F., 1973. Recherches sur l'uréogenèse chez les téléostéens dulcicoles. Thèse d'Ełat, Univ. Paul Sabatier, Toulouse, France. 159 pp.

ZEBIAN M. F., 1977. Fraction $\alpha$-aminée libre el dégradation oxydative de quelques acides aminés chez la carpe (Cyprinus carpio L.). Imporfance des facteurs nutrifionnels. Thèse $3^{\mathrm{e}}$ cycle, Univ. Paul Sabatier, Toulouse, France, 89 pp. 